\title{
PANCASILA SEBAGAI TEKS DIALOG LINTAS AGAMA DALAM PERSPEKTIF HANS-GEORG GADAMER DAN HANS KUNG
}

\section{Angel Ch. Latuheru}

Universitas Kristen Satya Wacana

Email: angelchlatuheru@gmail.com

\section{Izak Y. M. Lattu}

Universitas Kristen Satya Wacana

\section{Tony R. Tampake}

Universitas Kristen Satya Wacana

\section{Abstrak}

Artikel ini mengkaji tentang Pancasila sebagai teks dialog lintas agama di Indonesia. Indonesia sebagai negara yang plural secara khusus multi-agama melahirkan keunikan tersendiri. Namun, keunikan tersebut juga menimbulkan Konflik keagamaan karena sikap eksklusifisme, radikalisme, fundamentalisme agama dan politik identitas. Di tengah konflik keagamaan yang terjadi, dasar negara yakni Pancasila mampu menjaga kolektifitas masyarakat untuk tetap hidup bersatu sebagai Indonesia. Tulisan ini memakai teori Hermeneutik Gadamer untuk melihat teks sejarah bangsa Indonesia. Sejarah bukanlah sesuatu yang hanya terjadi di masa lampau dan terputus dengan konteks saat ini. Teori Etika Global-Hans Kung, juga membantu dalam melihat pentingnya dialog dalam kehidupan umat beragama dengan tujuan menciptakan perdamaian agama-agama. Tujuan dari penelitian ini ialah mendeskripsikan Pancasila sebagai teks dialog lintas agama di Indonesia. Metode yang dipakai ialah studi literatur untuk membantu menemukan ide-ide dan pendapat guna menganalisa dan memberi nilai tambah pada penelitian yang dilakukan. Pada akhirnya artikel ini menyimpulkan, bahwa Pancasila ialah ideologi final bagi bangsa Indonesia. Pancasila lahir sebagai pengalaman bersama dalam horizon perjuangan kemerdekaan dan diisi oleh nilai-nilai kebudayaan masyarakat Indonesia. Masyarakat multi-agama harus selalu ada dalam lingkaran dialog sebagai bentuk memahami Pancasila dalam konteks kehidupan umat beragama di Indonesia. Pancasila sebagai teks dialog lintas agama selalu 
dipahami secara dinamis, terbuka dan relevan dalam setiap perkembangan kehidupan beragama di Indonesia. Sebagai identitas nasional, Pancasila lebih dari suatu konsepsi merupakan penerang dan penuntun terhadap setiap strategi dialog yang dilakukan. Nilai-nilai Pancasila menumbuhkan sikap beragama yang inklusif, menghargai nilai-nilai kemanusiaan, dan menjadi landasan yang kokoh untuk menjaga kesatuan umat beragama.

Kata-kata Kunci: Pancasila, Teks, Hermeneutik, Dialog.

\section{Abstract}

This article addresses Pancasila as a text of interfaith dialogue in Indonesian context. The plurality of Indonesian society bears religious uniqueness in social life together, while conflicts may take place between religious groups. Religious conflicts are caused by attitude of exclusivism, radicalism, fundamentalism of religions and political identity. Pancasila can hold the sense collectivity among Indonesian society to be united. This article employs Gadamer hermeneutic theory in viewing historical texts. History is not something that only happened in the past and is interrupted with the present contexts. The theory of global ethics-Hans Kung, also helps the importance of dialogue with the religious communities to create religious peace. The article concludes that plural and multicultural society must live together in a dialogue circle. Pancasila as the text of interfaith dialogue is always understood as dynamic, open and relevant in the development of religious society in Indonesia. As the national identity, Pancasila has more than one conception as the lighters and guide toward each dialogue strategy that has been undertaken. The values of Pancasila maintain inclusive religious attitude, respect to human values, and become a solid foundation in maintaining the unity of religious people.

Keywords: Pancasila, Text, Hermeneutics, Dialogue.

\section{PENDAHULUAN}

Nusantara memiliki masyarakat dengan beragam identitas primordial suku, ras dan agama. Dalam usaha menjadi bangsa merdeka, maka disepakati dasar negara yakni ideologi Pancasila dan Undang-Undang Dasar NRI Tahun 1945. Proklamasi kemerdekaan negara Indonesia pada tanggal 17 Agustus 1945, merupakan titik awal masyarakat memperoleh identitas baru yakni identitas nasional Indonesia. Indonesia dengan dasar Pancasila sebagai identitas baru 
didirikan oleh masyarakat yang memiliki identitas primordial untuk mencapai kesatuan sebagai suatu masyarakat. Dapat dikatakan bahwa "Pancasila menggambarkan Realitas Indonesia"(Titaley, 2013).

Pluralisme dan multikultulturalisme masyarakat di satu sisi adalah suatu keunikan, tetapi di sisi lain juga berpeluang menimbulkan konflik khususnya konflik antarumat beragama. Agama dipakai untuk mencapai kekuasaan politik dan kepentingan ekonomi bagi segelintir orang (Sukiratnasari, 2015). Sikap eksklusivisme keagamaan juga menimbulkan persoalan seperti penistaan agama, hingga larangan beribadah bagi kelompok agama dan aliran kepercayaan (Amelia et al., 2016). Ekskluisivisme menimbulkan truth claim sehingga kebenaran dianggap hanya dimiliki oleh satu kelompok agama (Kuswanjono, 2006). Timbullah pemberian label "sesat" ataupun "kafir" kepada kelompok agama lain, yang memungkinkan konflik keagamaan terjadi (Bagir et al., 2013).

Kenyataan sosial kebangkitan agama-agama di ruang publik turut mematahkan paham sekularisme, yakni tersingkirnya agamaagama dari ruang publik ke ruang privat (Hendropuspito, 1983). Kebangkitan keagamaan terjadi karena meningkatnya kesadaran beragama dan kebangkitan gerakan-gerakan fundamentalisme (Huntington, 1996). Indonesia adalah salah satu negara yang menghadapi kebangkitan agama-agama di ruang publik dan fundamentalisme agama. Gerakan fundamentalisme agama bersikeras untuk menjalankan negara berbasis dogma agama. Kelompok ini tidak menyebut diri sebagai gerakan politik, tetapi melakukan fungsi politik. Dapat dikatakan gerakan-gerakan yang ingin mengganti ideologi Pancasila, termasuk dalam kategori anti-demokrasi, anti-pluralisme, dan anti-nasionalisme (Maarif et al., 2012). Menyikapi fundamentalisme dan radikalisme, maka pemerintah melakukan penegakan hukum, berdasarkan Perppu No 2 tahun 2017; tentang organisasi masyarakat. Dampak peraturan tersebuat ialah ormas HTI (Hizbut Tahrir Indonesia) dibubarkan tahun 2017, karena dianggap melakukan upaya dan aktivitas yang bertentangan dengan kehidupan ideologi Pancasila dan hukum Negara Kesatuan Republik Indonesia (Ihsanuddin, 2018). Berdasarkan konteks kehidupan beragama inilah, agama-agama di Indonesia harus tetap mengupayakan dialog 
(Widiyono, 2006). Dialog lintas agama dilakukan untuk menciptakan kedamaian bagi seluruh masyarakat.

Argumentasi yang ingin penulis sampaikan dalam tulisan ini ialah Pancasila merupakan teks bersama masyarakat Indonesia dalam pluralitas dan multikulturalisme yang dimiliki. Tiga tulisan yang menjadi pijakan awal penulisan artikel ini mengkaji Pancasila dalam bingkai disiplin ilmu sosiologi agama. Pemikiran John Titaley sangat berpengaruh ketika melihat Indonesia dengan dasar Pancasila sebagai fakta historis dan pengalaman religius masyarakat Indonesia. Menurut Titaley, kemerdekaan Indonesia dapat terjadi karena campur tangan Tuhan Yang Maha Esa, sehingga semua umat beragama terpanggil untuk menjaga pekerjaan Tuhan tersebut (Titaley, 2013). I Made Priana, dalam disertasinya "Misi Gereja Kristen Protestan di Bali Periode 20122016, dalam Perspektif Pancasila" melihat Pancasila sebagai agama sipil masyarakat Indonesia yang menumbuhkan kesadaran kolektif dan berfungsi sebagai kohesi sosial (Priana, 2017). Tedi Kholiludin dalam disertasinya "Pancasila dan Transformasi Religiusitas Sipil di Indonesia" memberikan sumbangsih baru yakni Pancasila merupakan milestone atau kisah bersama pluralitas bangsa Indonesia (Kholiludin, 2014). Kedua tulisan tersebut turut membahas Pancasila dengan menyentuh ranah hubungan lintas agama, tetapi tidak berfokus membahas Pancasila dalam konsepsi dialog atau Pancasila sebagai teks dialog lintas agama. Bagi penulis, sejak awal dalam perdebatan penentuan dasar negara, dialog menjadi bagian penting, baik dialog ideologi maupun dialog agama. Bagian inilah yang akan menjadi fokus penulisan dan membedakan tulisan ini dengan tulisan-tulisan sebelumnya.

Dialog yang terjadi dalam perjumpaan banyak agama hendaknya menyentuh persoalan konkret pertikaian umat manusia. Seringkali nilai-nilai agama dan budaya dipakai sebagai penuntun dialog, tetapi nilai-nilai tersebut tidak bisa dipakai secara general karena akan terjadi pemaksaan penerapan nilai-nilai agama dan budaya secara eksklusif kepada kelompok masyarakat yang berbeda agama dan budaya. Dengan demikian Nilai-nilai Pancasila merupakan nilai-nilai universal dalam kehidupan bermasyarakat. Pancasila dapat menjadi landasan dialog, karena Pancasila merupakan rumusan yang 
memungkinkan masyarakat multi agama hidup bersama dengan berbagai kepercayaan yang dimiliki. Pertanyaan kunci dalam tulisan ini adalah, bagaimana Pancasila dipahami sebagai teks bersama dialog lintas agama di Indonesia? Kajian ini merupakan kajian literatur dengan menggunakan metode deskriptif. Kajian ini berupaya menginformasikan kepada pembaca tentang berbagai hasil penelitian yang terdahulu, berbagai literatur terkait objek penelitian dan dihubungkan dengan penelitian yang dilakukan (Creswell, 2010).

Tulisan ini memakai dua teori; Pertama, Hermeneutik Gadamer dalam memahami teks sejarah. Teori ini menjadi penting karena hermeneutik Gadamer ialah suatu seni menjelaskan pengetahuan dan seni memahami teks. Teks tidak hanya dipahami dalam bentuk tulisan, tetapi realitas kehidupan juga merupakan teks (Gadamer, 2004). Kemajuan teori hermeneutik Gadamer ialah memahami hermeneutik dalam tingkatan ontologis bukan tingkatan metodologis sebagaimana yang dilakukan Schleiermarcher dan Dilthey. Kebenaran yang dicapai ialah proses dialektika dan bukan suatu metode (Gadamer, 2004., Hardiman, 2015). Kedua, Pandangan tentang dialog diambil dari ide Global Ethic-Hans Kung, yakni setiap tindakan manusia harus berdasarkan nilai-nilai etis yang bertanggung jawab. Menurut Kung, dialog akan kehilangan kredibilitas moral, jika dilakukan hanya pada tingkatan intelektual atau spiritual dan tidak peduli terhadap penderitaan sosial, fisik dan psikis dari jutaan manusia (Kung, 2003). Dialog membawa setiap individu beragama sampai pada kesadaran tentang realitas perbedaan, sehingga melahirkan sikap saling menghormati dan menghargai. Sasaran akhir dari dialog adalah kepentingan bersama atau menjunjung tinggi kemanusiaan dalam berbagai bentuk dialog (Dubut, 2009). Kedua teori ini sangat membantu memahami Pancasila sebagai teks historis bangsa Indonesia dan relevansinya dalam konteks kehidupan lintas agama di Indonesia pada Abad-21. Khususnya sebagai teks dialog lintas agama untuk menjaga kerukunan kehidupan masyarakat multi-agama.

\section{HERMENEUTIK, TEKS HISTORIS GADAMER, DAN GLOBAL ETIK KUNG}

Hermeneutik dan Teks Historis Hans-Georg Gadamer 
Hans-Georg Gadamer dalam bukunya Truth and Method, tidak bermaksud menjadikan hermeneutik sebagai suatu metode. Bagi Gadamer, kebenaran baru tidak bisa diungkapkan dengan metode karena metode hanya mampu memperlihatkan kebenaran yang implisit (Tarwiyani, 2011). Gadamer mengkritik hermeneutik F.D.E Schleiermarcher dan W.C.L Dilthey yang memandang hermeneutik sebagai tugas reproduksi, bahwa teks-teks kuno memiliki makna otentik yang dapat direkonstruksi secara utuh. Menurut Gadamer reproduksi makna secara utuh adalah kemustahilan. Penafsir hidup dan bergerak dalam sejarah dengan horizon pemahaman yang berbeda dengan horizon pemahaman penulis, ataupun teks yang hendak dipahami (Hardiman, 2014). Dengan demikian, hermeneutik tidak hanya terkait dengan metodologi penafsiran, tetapi terkait juga dengan penafsiran yang bersifat ontologi. Understanding juga merupakan the way of being dari manusia. Bagi Gadamer Hermeneutik merupakan usaha memahami dan menginterpretasi sebuah teks, teks keagamaan, teks seni, dan teks sejarah (Gadamer, 2004).

Pemikiran Gadamer banyak dipengaruhi oleh Martin Heidegger. Menurut Heidegger usaha untuk memahami teks dalam konteksnya, tidak diawali dengan kesadaran kosong yang kemudian secara temporer diisi dengan konteks saat ini. ketika memahami teks, seorang penafsir telah memiliki "pra-konsepsi" dalam cara pandang yang mapan, kemudian menggiringnya mencari maksud atau makna yang sesuai dengan konteks. Memandang dan memahami sejarah tidak berarti melepaskan diri dari konteks kekinian, melainkan pemahaman terhadap teks dapat terjadi jika dipandang dalam kesadaran dan situasi saat ini (Palmer, 2005). Heidegger memandang sejarah tidak terbatas pada konteks masa lalu, tetapi juga bekerja dalam konteks masa kini. Berdasarkan pengaruh pemikiran Heidegger, Gadamer kemudian menegaskan bahwa;

"Bukan hanya tradisi historis dan tatanan hidup alamiah yang merupakan kesatuan dunia tempat kita hidup sebagai manusia; cara kita mengalami dengan yang lain, cara kita mengalami tradisi historis, cara kita mengalami keterberian alamiah eksistensi dan dunia kita, merupakan alam 
hermeneutik sejati, yang di situ kita tidak terpenjara, seakanakan di belakang penghalang yang tidak bisa diatasi, tetapi kita justru terbuka (Gadamer, 2004)."

Sejarah bagi Gadamer adalah sebuah peristiwa masa lalu manusia yang diberi makna proyektif guna memandang masa depan, dengan kerangka berpikir hari ini. Dalam suatu pemahaman terhadap teks, unsur subjektifitas penafsir sangat sulit dihindari artinya penafsir juga mempengaruhi pengambilan makna (Gadamer, 2004). Memahami teks, tidak bisa dipisahkan dengan konteks masa kini, dan semata-mata melihat sejarah di balik teks.

"Setiap zaman harus memahami teks yang ditransmisikan dengan caranya sendiri, karena teks adalah bagian dari keseluruhan tradisi di mana suatu masa mengambil sebuah kepentingan objektif dan di mana ia berusaha untuk memahami dirinya sendiri. Makna real dari teks, sebagaimana ia tunjukkan pada penafsir, tidak tergantung pada kontingensi-kontingensi pengarangnya dan untuk siapa dia menulis. Pastinya ia tidak identik dengan mereka, karena sebagian selalu ditentukan juga oleh situasi historis penafsirnya dan oleh karena itu oleh totalitas perjalanan sejarah objektif (Gadamer, 2004)."

Dengan demikian dapat dikatakan bahwa; 'makna dari sebuah teks melampaui pengarangnya', sehingga pengarang tidak memiliki otoritas atas teks. Pemahaman tidak sebatas sikap reproduksi, tetapi juga produksi. Produksi tidak dimengerti sebagai pemahaman superior, pemahaman superior tentang subjek dengan ide-ide yang lebih jelas, akan tetapi suatu proses memahami dengan cara yang berbeda, jika benar-benar memahami (Gadamer, 2004).

Sejak awal proses memahami teks, pembaca teks telah memiliki prasangka atau prapaham berdasarkan fakta historisnya. Namun, prasangka menjadi legitimate atau tidak legitimate ditentukan berdasarkan tradisi dan otoritas. Otoritas tidak dianugerahkan, tetapi ditemukan saat seseorang memberi klaim padanya. Otoritas tidak bisa 
dipahami dalam kepatuhan buta terhadap perintah, tidak berhubungan dengan ketundukkan akan tetapi pengetahuan. Begitu juga dengan tradisi sebagai otoritas yang dipertahankan oleh romantisme, menjadi dasar dan memiliki kekuasaan terhadap sikap dan perilaku setiap individu. Tradisi memiliki kekuatan justifikasi yang berada di luar alasan logis dan menentukan kelembagaan serta sikap kita (Gadamer, 2004).

Memahami sejarah berarti memahami fenomena sejarah dalam karya-karya di masa silam dan juga pengaruh karya-karya tersebut di dalam sejarah. Gadamer menyebutnya sebagai Wirkungsgeschicte yang dapat diterjemahkan sebagai "sejarah pengaruh". Isitilah ini mengacu pada keterlibatan individu di dalam sejarah, yakni individu-individu yang menjadi pelaku sejarah, hidup di dalam sejarah dan tidak melampaui sejarah (Gadamer, 2004).

Melihat masa lalu dalam kesadaran historis juga berkaitan dengan horizon historitas. Horizon ialah bentangan visi yang melingkupi segala sesuatu, secara khusus dapat dilihat dari titik tolak tertentu. Dalam keasadaran historis yang demikian, pemahaman dapat dicapai dalam dimensi sejatinya (Gadamer, 2004). Pemahaman yang terbangun antara satu dengan yag lain, membentuk suatu horizon yang melampaui subjektivitas pengarang dan penafsir, sehingga terjadi penggabungan real horizon-horizon. Memahami bukanlah representasi makna dari masa silam, tetapi interaksi yang menghasilkan peleburan antara horizon masa silam dan horizon masa kini (Gadamer, 2004). Dapat disimpulkan bahwa suatu teks akan berbunyi dan hidup ketika dipahami, ditafsirkan dan diajak berdialog dengan pembacanya. Proses membaca dan memahami sebuah teks pada dasarnya merupakan suatu proses dialog untuk membangun sintesis antara dunia teks, dunia pengarang dan dunia pembaca.

\section{Global Ethic-Hans Kung}

Dialog adalah istilah yang sering didengar terutama berkaitan dengan pluralitas agama dan budaya. Secara etimologis dialog berasal dari bahasa Yunani, dia dan logein yang memiliki arti berbicara melalui (to speak through) yang menciptakan persatuan antara dua orang yang terlibat dalam sebuah pembicaraan yang jujur (Widiyono, 2006). Dialog 
tidak bisa lagi dipahami sebagai dialog yang ada pada tingkatan intelektual dan spiritual, karena dialog akan kehilangan kredibilitas moralnya. Dialog harus memperhatikan masalah penderitaan sosial, fisik, serta psikis dari jutaan manusia (Kung, 2003). Dokumen yang dikeluarkan oleh Dewan Kepausan untuk dialog lintas agama, memahami dialog dalam tiga tingkatan; Pertama, tingkatan manusiawi, dialog merupakan komunikasi timbal-balik yang mengarah pada tujuan bersama, atau mengarah pada persatuan antarpribadi. Kedua, dialog sebagai bentuk penghormatan dan persahabatan yang meresapi hubungan antara berbagai kelompok agama. Ketiga, dalam konteks keragaman agama, dialog merupakan hubungan antaragama yang positif dan konstruktif dengan pribadi ataupun komunitas dari agama lain (Rahmat, 2017).

Hans Kung, seorang teolog katolik yang cemerlang, sekaligus penuh dengan "kontroversi", membangun wacana tentang etika global (Sumartana, 1999). Dunia baik secara politik, teknologi, ekonomi, maupun peradaban, memerlukan etika dunia. Sebuah konsensus dasar yang menyepakati nilai-nilai yang mengikat, standar-standar yang tidak dapat diganggu gugat, yang menentukan sikap personal. Etika global adalah nilai-nilai kemanusiaan yang mendasari kehidupan setiap umat beragama, namun tidak mengganti nilai-nilai primordial yang tertanam dalam setiap agama (Kung, 1998). Bukanlah kesatuan agama di atas semua agama yang ada, dan bukan dominasi satu agama atas agama lainnya, melainkan menghadirkan batas minimal etik yang patut dimiliki bersama oleh semua agama dunia (Titaley, 2013).

Menghadapi perkembangan kehidupan masyarakat yang semakin multi-kultural dan multi-religius, Kung berpendapat bahwa jalan satu-satunya bagi hubungan antaragama yakni "persaudaraan antaragama". Lebih jauh ia juga menekankan; "There will be no peace between the civilizations without a peace between the religions! And there will be no peace between the religions without a dialogue between the religions" sebagai respons terhadap konflik peradaban (Kung, 1998). Proposisi penting yang disampaikan Hans Kung dalam bukunya Global Responsibility yakni; a) agama-agama tidak lagi berusaha saling menyingkirkan atau mengalahkan dalam pelaksanaan misi keagamaan; b) agama-agama tidak berusaha menciptakan satu agama 
tunggal, sebagai bentuk penyatuan dari berbagai agama di dunia; b) agama-agama hidup saling berdampingan dengan sikap saling menghormati, dalam kesadaran dialog dan kerja sama (Sumartana, 1999).Terdapat empat batas minimal etik yang patut dimiliki, dalam membangun etika global; Pertama, nilai non kekerasan dan hormat pada kehidupan; kedua, nilai solidaritas dan tata ekonomi yang adil; ketiga, nilai toleransi dan hidup yang tulus; keempat, nilai kesejajaran hak dan kerja sama antara laki-laki dan perempuan (Kung \& Kuschel, 1999).

Dialog lebih dari sekedar minat intelektual akademis, dialog hendaknya mencakup masalah penderitaan jutaan manusia yang terhina dan terkucilkan karena hak dan martabat mereka ditolak. Terwujud dalam dialog tindakan (dialog of action) dan dialog kehidupan (dialog of life) yang dilakukan dalam realitas konkret masyarakat. Maka dialog lintas agama harus menyertakan suatu etika global (global ethic) dan tanggung jawab global (global responsibility). Seperti yang ditulis parlemen agama-agama se-Dunia (world parliament of Religions) di Chicago tahun 1993 dalam “Deklarasi untuk suatu Etika Dunia." Dunia bisa mencapai perdamaian dan keadilan yang lebih besar jika semua agama secara bersama mengakui bahwa kebenaran juga berada dalam agama lain. Agama-agama dunia harus mengakui tanggung jawab untuk bekerja sama demi keadilan menyeluruh, perdamaian yang lebih abadi, dan hubungan yang lebih langgeng dengan ekosistem (Kung, 2003).

Setiap agama bekerja sama membangun dialog demi terwujudnya perdamaian dan keadilan yang merupakan tanggung jawab global. Melepaskan sikap eksklusifisme dengan memahami agama dalam suatu kenyataan sosial-historis adalah titik awal setiap agama berteologi sesuai konteks kehidupannya.

\section{PANCASILA DAN KE-INDONESIAAN}

Pancasila merupakan nilai-nilai yang diambil dari budaya bangsa Indonesia untuk mengatur kehidupan bersama. Dalam upaya untuk memahami Pancasila sebagai teks dialog lintas agama, maka penting untuk mengkaji Pancasila secara historis. Sejarah bersama 
sebagai Indonesia dengan dasar Pancasila merupakan penjaga kolektivitas masyarakat.

Secara historis titik tolak pergerakan kemerdekaan ialah kesamaan nasib sebagai yang terjajah oleh imperialisme dan kolonialisme. Sistem penjajahan Belanda sangat menyengsarakan rakyat karena sistem kapitalis dijalankan tanpa memiliki basis gronstoffen (sumber daya) (Malaka, 2000). Sehingga sumber daya seluruhnya diambil dari negeri jajahan. Pergerakan kemerdekaan ini berlangsung hampir seratus tahun dan sepanjang abad ke-19, tetapi pergerakan kemerdekaan belum dilakukan secara serentak. Perjuangan dilakukan secara sendiri-sendiri sesuai dengan kepentingan daerah, golongan dan agama. Walaupun demikian perjuangan tersebut merupakan cikal bakal gerakan kemerdekaan rakyat secara serentak (Kartodirdjo et al., 1957). Di awal abad ke-20, pergerakan kemerdekaan Indonesia sudah berskala Nusantara. Generasi muda yang sempat mengenyam pendidikan tinggi mulai mengenal dan mengetahui etika pasca Revolusi Prancis Barat yakni memiliki hak menentukan nasib sendiri, nasionalisme, dan sosialisme (Suseno, 2012). Usaha mencapai kemerdekaan selain perlawanan terhadap penjajah, yakni mempersiapkan diri menjadi sebuah negara, salah satunya menyusun Philosofische Grondslag. Ideologi Nasionalisme, Islamisme, dan Sosialis-Marxis menjadi landasan pemahaman organisasi-organisasi yang berdiri di awal abad ke 20 . Dialog yang terjadi antara ke tiga ideologi tersebut menjadi pokok utama dalam melihat perumusan Pancasila sebagai dasar negara.

\section{NILAI-NILAI PANCASILA}

Indonesia dan Pancasila dipahami sebagai suatu komitmen dan pandangan hidup bersama sebagai satu bangsa baru (Titaley, 2013). Menurut Yudi Latif, Pancasila didasari oleh gotong-royong, karena negara Indonesia yang didirikan haruslah negara gotong-royong. Prinsip Ketuhanan yang berjiwa gotong-royong yakni Ketuhanan yang berkebudayaan, yang terbuka dan toleran, bukanlah Ketuhanan yang eksklusif saling menyerang dan mengucilkan. Prinsip internasionalisme berjiwa gotong-royong yakni berperikemanusiaan dan berperikeadilan, tidak menjajah dan mengeksploitasi. Prinsip 
kebangsaan berjiwa gotong-royong yakni menerima dan mengembangkan persatuan dalam berbagai perbedaan "bhinneka tunggal ika." Prinsip demokrasi yang berjiwa gotong-royong dengan mengembangkan musyawarah mufakat, sehingga demokrasi tidak hanya mengikuti suara mayoritas atau minoritas elite (penguasa atau pemodal). Prinsip kesejahteraan yang berjiwa gotong-royong dengan mengembangkan partisipasi dan perubahan di bidang ekonomi dengan semangat kekeluargaan, sehingga tidak bersifat individualisme-kapitalisme dan tidak mengekang kebebasan individu (Latif, 2012). Dengan demikian hidup bergotong-royong membuat masyarakat bermusyawarah ketika merumuskan kesepakatan untuk kepentingan bersama (Soeprapto, 2013).

Dalam penyusunan urutan pancasila tidak bersifat prioritas, tetapi justru masing-masing sila saling kait mengait (Priana, 2017). Makna setiap Sila dalam Pancasila dapat dijabarkan sebagai berikut;

1. Sila Ketuhanan Yang Maha Esa; sila pertama sebagai dasar yang memimpin, artinya kelima sila dari pancasila tidak bisa dilepas pisahkan, sila yang satu harus berjalan dengan sila-sila lainnya. Perpaduan dari segala aliran agama dan kepercayaan melahirkan sila pertama (Latif, 2015). Soekarno dalam pandangannya tentang sila KeTuhanan Yang Maha Esa, memberikan makna yang penting dalam konteks kehidupan beragama.

“... Prinsip K e t u h a n a n! Bukan saja bangsa Indonesia berTuhan, tetapi masing-masing orang Indonesia hendaknya ber-Tuhan. Tuhannya sendiri. Yang Kristen menyembah Tuhan menurut petunjuk Isa al Masih, yang Islam ber-Tuhan menurut petunjuk Nabi Muhammad saw, orang Buddha menjalankan ibadatnya menurut kitab-kitab yang ada padanya. Tetapi marilah kita semua ber-Tuhan. Hendaknya Negara Indonesia ialah negara yang tiap-tiap orangnya dapat menyembah Tuhannya dengan cara yang leluasa. Segenap rakyat hendaknya ber-Tuhan secara kebudayaan, yakni dengan tiada "egoisme-agama". Dan hendaknya Negara Indonesia satu Negara yang ber-Tuhan! (Bahar and Hudawati, 1998)" 
Ber-Tuhan secara kebudayaan, sehingga tidak ada egoismeagama antara pemeluk agama yang berbeda. Cara berkeadaban dalam ber-Tuhan, dengan menghormati satu sama lain dalam menghayati keber-Tuhanan mereka. Pandangan ini memberikan kebebasan kepada setiap orang untuk ber-Tuhan, sehingga setiap agama mendapat tempat yang sama dan sebaik-baiknya.

2. Sila Kemanusiaan Yang Adil dan Beradab; artinya bangsa menghargai kemanusiaan rakyatnya. Kepercayaan kepada Tuhan yang Maha Esa, akan kehilangan makna jika kemanusiaan tidak dipentingkan (Bolo et al., 2012). Rakyat yang plural, berbeda-beda suku, ras, dan agama, merupakan manusia yang setara dan diperlakukan secara manusiawi serta bermartabat. Setiap manusia Indonesia menumbuhkan rasa kemanusiaan yang penuh dengan cinta terhadap yang lain (Latif, 2015).

3. Sila Persatuan Indonesia; Indonesia adalah suatu kesatuan, sehingga negara ini menetapkan semboyan Bhinneka Tunggal Ika sebagai suatu pengakuan atas keberagaman masyarakat Indonesia, yang diikat dalam bingkai kesatuan. Terdapat penekanan bahwa bangsa ini menjadi Indonesia karena adanya kolektivisme, masyarakat bersatu untuk memperjuangkan kemerdekaan, sehingga masyarakat juga harus bersatu untuk menjaga negara Indonesia (Priana, 2017).

4. Sila Kerakyatan yang Dipimpin oleh Hikmat Kebijaksanaan dalam Permusyawaratan/Perwakilan; demokrasi yang dianut oleh Indonesia bukanlah kerakyatan yang mencari suara terbanyak, namun kerakyatan yang dipimpin oleh hikmat dalam permusyawaratan perwakilan. Demokrasi ini dihidupi dalam rasionalitas, dan semangat untuk saling menghormati, dengan memandang manusia lain sebagai subjek yang berdaulat. Indonesia adalah tempat bagi semua rakyat sehingga rakyat mampu mewujudkan kebebasan karena adanya persamaan, persaudaraan dan kekeluargaan (Priana, 2017).

5. Sila Keadilan Sosial Bagi Seluruh Rakyat Indonesia; kemanusiaan masyarakat Indonesia sangat dihargai dalam konteks kehidupannya secara nyata, sehingga memperbaiki taraf hidup rakyat secara fisik menjadi penting. Sistem ekonomi Indonesia bukan kapitalis dan juga bukan sosialis, tetapi sosialis khas Indonesia. Sosialis khas 
Indonesia merupakan perpaduan dari apa yang baik dari kapitalis dan sosialis, dan juga penghilangan yang buruk dari kedua sistem tersebut (Priana, 2017).

\section{DIALOG IDEOLOGI DAN DIALOG AGAMA Dialog Ideologi}

Nasionalisme, Islamisme, dan Sosialis-Marxis (Priana, 2017), awalnya merupakan landasan ide organisasi. Marxisme resmi di Indonesia, saat berdirinya Indische Sociaal Democratische Vereeniging (ISDV) atau Serikat Sosial Hindia-Belanda, pada tahun 1914. ISDV membangun kerja sama dengan Sarekat Islam (SI), terlihat dalam kritik terhadap pemerintah tentang ketertindasan kaum buruh karena dipandang sebagai alat produksi dengan upah yang kecil. Saat itu pemerintah bertindak melindungi kapitalisme, sehingga kapitalisme tumbuh subur dan usaha meraih kemerdekaan melemah. Kritik tersebut disampaikan dalam kongres Nasional Sarekat Islam ke-tiga di Surabaya, pada tanggal 29 Oktober 1918 (Kasenda, 2014). Pada tahun 1920, terbentuk Perserikatan Komunis di Hindia (PKH) Pada aplikasinya terdapat perbedaan paham antara Partai Komunis yang berasas Marxisme dan Sarekat Islam yang berasas Islamisme, sehingga timbul pertentangan antara satu dengan yang lain (Kasenda, 2014).

Pada tanggal 4 Juli 1927, terbentuk Partai Nasional Indonesia (PNI) yang dipimpin oleh Soekarno. Sejumlah anggota Partai Komunis Indonesia tergolong dalam Partai Nasional Indonesia, akan tetapi Soekarno menegaskan bahwa PNI bukanlah warisan PKI, namun tujuan kedua partai sama yakni melawan imperialisme Barat (Dahm, 1987., Kasenda, 2014). Soekarno menimbang bahwa, jika golongan Islam memperjuangkan kemerdekaan, maka akan berdiri negara Islam di Nusantara. Bila hanya golongan komunis yang memperjuangkan kemerdekaan, maka kemungkinan besar Nusantara akan dibentuk menjadi negara komunis. Dengan demikian, Soekarno menginginkan ketiga golongan bersatu memperjuangkan kemerdekaan untuk membentuk negara Indonesia, sebagai rumah bersama (Priana, 2017).

Perumusan dasar negara menjadi titik tolak terbentuknya "Badan Penyelidik Usaha Persiapan Kemerdekaan Indonesia (BPUPKI)" atau Dokuritsu Zyunbi Chosakai (1 Maret 1945) (Abdullah, 
1998) dan "Panitia Persiapan Kemerdekaan Indonesia (PPKI)" atau Dokuritsu Zyunbi Linkai. BPUPKI dibentuk dengan tujuan untuk mengkaji dan menelaah, sedangkan peran PPKI adalah untuk mengambil keputusan (Abdullah, 1998), yang diharapkan mampu mewujudkan pernyataan resmi perdana mentri Jepang Kaiso pada bulan September 1944 tentang janji kemerdekaan Indonesia (Abdullah, 1998).

Pada sidang pertama BPUPKI (29 Mei - 1 Juni 1945) terdapat berbagai pendapat dari tokoh-tokoh dengan paham Nasionalisme, Islam, dan Sosialis-Marxis (Abdullah, 1998). Tokoh-Tokoh dari ketiga golongan yang menyampaikan pendapat ialah; Mr. Muhammad Yamin dalam pidatonya tanggal $29 \mathrm{Mei}$, memberikan saran tentang dasar negara yang terdiri dari Peri Kebangsaan, Peri Kemanusiaan, Peri Ketuhanan, Peri Kerakyatan dan kesejahteraan rakyat. Pada tanggal 31 Mei, Ki Bagoes Hadikoesomo, sebagai tokoh Islam, menyarankan Islam sebagai dasar negara, dengan pertimbangan mayoritas masyarakat Indonesia beragama Islam.

“... Jika tuan-tuan bersungguh-sungguh menghendaki Negara Indonesia mempunyai rakyat yang kuat bersatu padu berdasar persaudaraan yang erat dan kekeluargaan serta gotong-royong, didirikanlah negara kita ini di atas petunjuk-petunjuk Al-Qur'an dan Al-Hadist..."(Bahar and Hudawati, 1998)

Berbeda dengan pandangan Ki Bagoes Hadikoesomo, Prof. Mr. Dr. Soepomo pada tanggal $31 \mathrm{Mei}$, menyampaikan tiga teori negara, yang disebut teori perseorangan, teori golongan, dan teori integralistik. Teori integralistik, menurut Soepomo sesuai dengan aliran pikiran ketimuran. Dengan pandangan bahwa pemimpin bersatu jiwa dengan rakyat, maka Soepomo memandang tidak perlu diadakan jaminan hakhak warganegara secara eksplisit dalam Undang-undang Dasar (Abdullah, 1998).

“...terpenting dalam negara yang berdasar aliran pikiran
integral ialah penghidupan bangsa seluruhnya. Negara 
tidak memihak kepada sesuatu golongan yang paling kuat, atau paling besar, tidak menganggap kepentingan seseorang sebagai pusat akan tetapi negara menjamin keselamatan hidup bangsa seluruhnya sebagai persatuan yang tidak dapat dipisahkan..."(Bahar and Hudawati, 1998)

Soepomo jelas ingin mengusulkan negara yang berdasarkan pemikiran integral yakni negara persatuan. Dengan demikian konsep mendirikan negara Indonesia menjadi negara Islam, tidak disetujui dengan berbagai pertimbangan konteks kebangsaan.

“... seandainya kita di sini mendirikan negara Islam, pertentangan pendirian itu akan timbul juga di masyarakat kita dan barangkali Badan Penyelidik ini pun akan susah memperbincangkan soal itu. Akan tetapi, Tuan-tuan yang terhormat, akan mendirikan negara Islam di Indonesia berarti, tidak akan mendirikan negara persatuan. Mendirikan negara Islam di Indonesia berarti mendirikan negara yang akan mempersatukan diri dengan golongan yang terbesar, yaitu golongan Islam. Jikalau di Indonesia didirikan negara Islam, maka tentu akan timbul soal-soal "minderheden", soal golongan agama yang kecil-kecil, golongan agama Kristen dan lain-lain. Meskipun negara Islam akan menjamin dengan sebaik-baiknya kepentingan golongan-golongan lain itu, akan tetapi golongangolongan agama kecil itu tentu tidak bisa mempersatukan dirinya dengan negara. Oleh karena itu, cita-cita negara Islam itu tidak sesuai dengan cita-cita negara persatuan yang telah diidam-idamkan oleh kita semua dan juga yang telah dianjurkan oleh Pemerintah Balatentara."(Bahar and Hudawati, 1998)

Perbedaan pandangan golongan nasionalisme dan golongan Islam, didasarkan kepentingan setiap golongan untuk memperjuangkan 
pandangan ideologinya. Perbedaan pendapat tidak bisa dihindari oleh karena itu dialog ideologi terjadi dalam usaha memahami.

Pada tanggal 1 Juni, Ir. Soekarno hadir dengan pemikiran yang menyatukan ketiga ideologi tersebut dalam rumusan dasar negaranya. Soekarno menyarankan lima prinsip dasar negara yang disebut sebagai Pancasila, terdiri dari kebangsaan; internasionalisme atau perikemanusiaan; mufakat, atau demokrasi; kesejahteraan; dan Ketuhanan. Selain itu terdapat konsep Trisila menurut pandangan Soekarno, yang terdiri dari sosio-nasionalisme, sosio-demokrasi, dan Ketuhanan yang menghormati satu sama lain. Pilihan ketiga yang ditawarkan Soekarno yakni gotong royong atau disebutnya sebagai Ekasila. Soekarno menyebut Pancasila sebagai Weltanschauung, dan untuk mencapainya dibutuhkan perjuangan (Abdullah, 1998).

Konsep besar yang digagas Soekarno yakni, NASAKOM (Nasionalisme, Agama, dan Komunisme) (Priana, 2017). Soekarno selalu menampilkan dirinya sebagai pribadi yang nasionalis, sekaligus Muslim, dan juga seorang yang berada dalam golongan kiri (komunis). Soekarno berupaya untuk menghimbau kepada semua golongan bahwa mereka merupakan bagian dari Indonesia dan harus bergotongroyong untuk membangun negeri dan mengharuskan adanya perjuangan demi kepentingan bangsa dan negara Indonesia. Konsep penyatuan Nasionalis, Islamis, dan Marxis adalah sebuah eksperimen Soekarno untuk Indonesia (Soekarno, 1964).

\section{Dialog Agama}

Dialog agama juga terjadi dalam penyusunan dasar negara dan bentuk negara pada sidang BPUPKI dan PPKI. Hasil persetujuan panitia kecil beranggotakan sembilan orang yang dibentuk BPUPKI, mencapai persetujuan rancangan preambule hukum dasar, sebagai gentlemen agreement antara paham Nasionalis dan Islam (Bahar \& Hudawati, 1998). Hasil kesepakatan tersebut ialah rumusan piagam Jakarta yang disetujui pada tanggal 22 Juni 1945 (Abdullah, 1998). Perubahan yang dihasilkan cukup substansial, jika dibandingkan dengan pandangan Soekarno sebelumnya, yaitu; Prinsip Pertama, ketuhanan dengan kewajiban menjalankan syri' at Islam bagi pemelukpemeluknya; Prinsip kedua, kemanusiaan yang Adil dan Beradab; 
Prinsip ketiga, persatuan Indonesia; Prinsip keempat, kerakyatan yang dipimpin oleh hikmat kebijaksanaan dalam permusyawaratan atau perwakilan; Prinsip kelima, keadilan sosial bagi rakyat Indonesia (Abdullah, 1998). Terkhususnya pada prinsip Ketuhanan menjadi menarik untuk diperhatikan. Bahkan dalam konsep Trisila Ir. Soekarno mengusulkan salah satu poin yakni "Ketuhanan yang menghormati satu sama lain", namun dalam dasar negara yang digagas BPUPKI, agama Islam mendapatkan tempat yang istimewa dibandingkan dengan agama-agama lain.

Kritik terhadap Piagam Jakarta, salah satunya di sampaikan oleh Masjkoer, tentang "menjalankan syariat Islam bagi pemelukpemeluknya" dan mempertanyakan "Apakah Presiden bisa beragama selain Islam ? (Bahar \& Hudawati, 1998)." Tanggapan Soekarno terhadap pernyataan dan pertanyaan Masjkoer, sangat menekankan konsepsi dirinya sebagai seorang Muslim.

"Kalau Tuan Haji Masjkoer menanyakan hal itu kepada diri saya sebagai person Soekarno, saya seyakin-yakinnya, bahwa Presiden Indonesia tentu orang Islam. Tak lain dan tak bukan ialah oleh karena saya melihat dan mengetahui bahwa sebagian besar dalam pidato saya di dalam sidang pertama, saya telah menganjurkan sebagai orang Islam, menganjurkan kepada umat Islam Indonesia, supaya bekerja keras untuk mempropagandakan agama Islam sehebathebatnya dalam kalangan rakyat Indonesia, sehingga jikalau betul sebagian besar daripada rakyat Indonesia itu jiwanya berkobar dengan api Islam, rohnya menyala-nyala dengan ruh Islam, tidak boleh tidak, bukan saja Presiden Republik Indonesia nanti orang Islam, bahkan- saya berkata, - tiaptiap Undang-undang yang keluar daripada badan perwakilan bercorak Islam pula (Bahar \& Hudawati, 1998)."

Tanggapan Soekarno secara personal, memperlihatkan bahwa identitas primordial sebagai seorang Muslim tidak bisa ditinggalkan. Keyakinan yang mendarah dan mendaging, turut diperjuangkan untuk memiliki hak yang istimewa karena mayoritas masyarakat 
Indonesia beragama Islam. Perjuangan tersebut juga dilakukan oleh anggota BPUPKI yang lain dengan identitas keagamaan yang berbeda.

Prinsip "Ketuhanan dengan kewajiban menjalankan syariat Islam bagi pemeluk-pemeluknya" mendapatkan kritikan-kritikan dalam sidang kedua BPUPKI (10-17 Juli 1945). Dalam pokok rancangan pembukaan UUD, Bagoes Hadikoesoemo dan Ki Sanusi sebanyak empat kali menyampaikan saran tanggal 31 Mei 1945, bahwa anak kalimat tersebut sebaiknya dihapuskan dengan alasan negara harus netral terhadap agama dan timbulnya kekhawatiran akan terjadi perpecahan dalam masyarakat jika terdapat dua macam hukum yang berbeda. Usul kedua anggota ini ditolak oleh ketua BPUPKI Dr. Radjiman Wedyoningrat maupun oleh ketua Panitia Perancangan UUD Ir. Soekarno (Abdullah, 1998).

Latuharhary sebagai perwakilan Indonesia timur, yang berkeyakinan Kristen, secara tegas mengatakan sikap tidak setuju dengan semua perkataan tentang "ke-Tuhanan".

"Akibatnya akan besar sekali. Umpamanya terhadap pada agama lain... yang mewajibkan syariat Islam pada pemelukpemeluknya, yaitu bagaimana mewajibkan untuk menjalankannya? Salah satu anggota mengatakan pada saya bahwa terhadap pada adat-istiadat di Minagkabau, rakyat yang menjalankan agama Islam harus meninggalkan adatistiadatnya. Dan umpamanya di Maluku hak tanah bersandar atas adat-istiadat sepenuhnya. Agama Islam maupun Kristen dalam hal ini tidak dapat mencampuri. Kalau diwajibkan pada pemeluk-pemeluk agama Islam untuk menjalankan syariat Islam, sudah tentu kalimat ini akan dipergunakan terhadap pada adat-istiadat di sini, umpamanya terhadap hak tanah. Tanah itu bukan saja diwariskan pada anak-anak yang beragama Islam, tetapi juga yang beragama Kristen. Jadi, kalimat semacam itu dapat membawa kekacauan yang bukan kecil terhadap adatistiadat (Bahar \& Hudawati, 1998)." 
Pendapat Latuharhary mendapatkan penolakkan dari berbagai kelompok BPUPKI, yang tetap mempertahankan dilaksanakannya "Syariat Islam" dalam kehidupan bernegara. Soekarno juga menyampaikan pendapat bahwa Piagam Jakarta adalah preambule yang menghilangkan perselisihan paham antara golongan Islam dan Nasionalis (Bahar \& Hudawati, 1998).

Pada tanggal 17 Agustus 1945 sore, setelah proklamasi kemerdekaan, timbul permintaan tokoh-tokoh masyarakat Indonesia bagian timur (Abdullah, 1998) kepada Drs. Mohammad Hatta agar anak kalimat yang memuat "tujuh kata" dicoret. Atas permintaan tersebut, tokoh-tokoh Islam Ki Bagus Hadikusomo, dan Kiai Sanusi bersama dengan K.H Wachid Hasyim, Mr. Tengku Mohammad Hassan, dan Mr. Kasman Singodimedjo, menyambut baik permintaan tokoh-tokoh masyarakat Indonesia bagian Timur (Abdullah, 1998).

Sidang pertama PPKI tanggal 18 Agustus 1945 pagi, masalah anak kalimat dalam alinea keempat rancangan pembukaan UndangUndang Dasar 1945 yakni "Ketuhanan, dengan kewajiban menjalankan syariat Islam bagi pemeluk-pemeluknya," telah diganti dengan persetujuan dari tokoh-tokoh Islam. Dengan demikian berubah menjadi "Ketuhanan yang Maha Esa” (Abdullah, 1998).

Selain penghapusan tujuh kata yang memberikan perubahan di dalam pancasila sebagai dasar negara, di dalam pembukaan UndangUndang Dasar frase, "atas berkat Allah yang Maha Kuasa" diganti menjadi "Atas berkat Tuhan yang Maha Kuasa". Usul I Gusti Ktut Pudja, dengan alasan konsep Tuhan lebih netral dan mudah dipahami dalam agama Hindu ketimbang konsep Allah (Bahar \& Hudawati, 1998). Kesepakatan PPKI terkait digantinya kata "Allah" dengan "Tuhan" tidak termuat dalam berita Republik Indonesia tahun II no 7, yang terbit pada tanggal 15 Februari 1946, sehingga kalimat tersebut tetaplah "Atas berkat Allah yang maha Kuasa". Menurut keterangan dalam Risalah Sidang BPUPKI-PPKI, hal tersebut kemungkinan besar merupakan kesalahan teknis dalam suasana revolusi saat itu (Bahar \& Hudawati, 1998., Kholiludin, 2014).

Sila Ketuhanan Yang Maha Esa, adalah hasil kesepakatan untuk kepentingan bersama. Ketuhanan Yang Maha Esa memiliki peranan yang penting, karena hanya dalam konteks kehidupan bersama 
sebagai Indonesia Sila ini dapat dimengerti. Menurut Eka Darmaputra, Sila Ketuhanan Yang Maha Esa tidak bisa dimengerti hanya sebagai prinsip toleransi, akan tetapi dalam terang Sila pertama inilah, keempat sila lainnya dapat dipahami dan ditafsirkan (Darmaputera, 1992).

\title{
PANCASILA SEBAGAI TEKS DIALOG LINTAS AGAMA DAN RELEVANSI PANCASILA PADA KONTEKS KEKINIAN
}

Pancasila sebagai teks dialog lintas agama ialah teks yang lahir dalam konteks sosial-politik masyarakat terjajah yang menginginkan kemerdekaan, dengan tetap mempertahankan pluralitas masyarakat Indonesia khususnya pluralitas agama. Pancasila menjadi nilai bersama yang membuka ruang perjumpaan dan dialog lintas agama dalam kehidupan bermasyarakat. Memahami Pancasila sebagai teks menjadikan Pancasila tetap relevan dalam kehidupan masyarakat Indonesia dari zaman ke zaman. Sehingga Pancasila tidak menjadi ideologi yang statis, tertutup dan kehilangan relevansi.

Secara historis, Pancasila merupakan kristalisasi nilai-nilai yang diyakini kebenarannya oleh bangsa Indonesia. Sebagaimana yang disampaikan Soekarno bahwa:

\begin{abstract}
"Aku hanya menggali Pancasila daripada buminya Bangsa Indonesia. Pancasila terbenam di dalam bumi Bangsa Indonesia 350 tahun lamanya - aku gali kembali dan aku sembahkan Pancasila ini di atas persada Bangsa Indonesia kembali."(Darmaputera, 1992)
\end{abstract}

Jika Pancasila dipahami sebagai suatu pandangan hidup yang tercermin dalam khasanah adat-istiadat, kebudayaan, dan keagamaan (Kaelan, 2013:56), maka Pancasila sebagai teks diberikan makna proyektif guna memandang masa depan bangsa Indonesia. Seperti pandangan Gadamer bahwa, sejarah merupakan peristiwa masa lalu yang diberikan makna proyektif untuk memandang masa depan. Sistem nilai yang diwariskan oleh tradisi menjadi penting dan konteks penafsir juga tidak bisa dinafikan (Gadamer, 2004). Pancasila sebagai sistem nilai yang diwariskan, tidak bisa diambil maknanya tanpa melihat tantangan yang dihadapi oleh konteks kehidupan saat ini. 
Soekarno menyebut Pancasila sebagai Weltanschauung, dan untuk mencapainya dibutuhkan perjuangan (Abdullah, 1998). Weltanschauung dalam konsep pemikiran Gadamer, tergolong dalam bildung. Bildung teoritik adalah penalaran untuk mengikuti sesuatu yang berbeda daripada dirinya, dapat memahami sesuatu, yang objektif di dalam kebebasannya, tanpa mementingkan diri sendiri (Gadamer, 2004). Pancasila sebagai hasil kesepakatan bersama, tidak mementingkan satu golongan atau ideologi tertentu, tetapi kepentingan semua golongan dan masyarakat. Pancasila dalam proses penetapannya, ada dalam berbagai gejolak dan pertentangan. Pertentangan pendapat antara golongan Nasionalis, Islam dan SosialisMarxis. Pertentangan pandangan merupakan wujud dari ketidakterpahaman antara berbagai golongan, sehingga dialog yang terjadi bertujuan untuk memberikan pemahaman dan mencapai kesepakatan. Memahami antara satu dengan yang lain terjadi saat mereka berdialog dan mencapai persetujuan, sehingga pemahaman merupakan pemahaman tentang sesuatu (Gadamer, 2004). Dialog antara golongan golongan Nasionalis, Islam dan Sosialis-Marxis memberikan pengalaman perjumpaan dalam perbedaan, sehingga Founding Fathers harus menemukan landasan bernegara untuk kepentingan bersama.

Kehidupan beragama saat ini diwarnai dengan radikalisme dan fundamentalisme agama yang memiliki tujuan politik mendirikan 'negara agama'. Gerakan keagamaan ini seringkali hadir di ruang publik dan lantang bersuara menyatakan pilihan-pilihan politik. Dalam pemahaman masyarakat Indonesia yang sangat mementingkan agama, sulit untuk mendorong agama keluar dari ruang publik. Keterlibatan simbol keagamaan, dipengaruhi politik dan ekonomi, bagi sebagian masyarakat Indonesia merupakan sesuatu yang wajar. Namun, mereka juga menyadari bahwa keterlibatan dan pencampuran antara agama, politik dan ekonomi berpotensi menimbulkan permasalahan (Noor \& Ferry Muhammadsyah Siregar, 2014). Kondisi semacam ini jelas terlihat dalam kontestasi politik, sejak pemilihan Gubernur DKI Jakarta pada tahun 2017 dan pemilihan presiden tahun 2019, isu keagamaan sangat kental. 
Agama Islam sebagai mayoritas di Indonesia, memegang peranan penting di ruang publik. Beberapa gerakan fundamentalis Islam, bertujuan menjadikan Indonesia sebagai negara berdasarkan Syari'at Islam. Dalam pembahasan sebelumnya, Islam merupakan salah satu idelogi yang berperan dalam proses pembentukan dasar negara. Walaupun awalnya agama Islam mendapatkan hak khusus dalam ketetapan Piagam Jakarta, tetapi kesepakatan akhir yang diambil memberikan hak istimewa kepada semua agama. Kata "dengan kewajiban menjalankan Syari'at Islam bagi pemelukpemeluknya" diganti menjadi "Ketuhanan Yang Maha Esa". Atas dasar inilah semua agama dan aliran kepercayaan mendapat tempat yang setara di negara Indonesia. Pancasila kemudian memberikan jaminan kepada masyarakat untuk bebas memeluk dan menjalankan keyakinan agamanya (Soeprapto, 2013).

Dari perspektif hermeneutik dan teks historis Gadamer, penulis memahami Pancasila sebagai historical experience. Tidak dalam pengertian sempit bahwa Pancasila hanyalah kenyataan pengalaman sejarah masa lampau. Namun, Pancasila lahir dari penderitaan bersama masyarakat terjajah dan lebih dari pada itu kehidupan masyarakat Indonesia setelah merdeka juga dihidupi serta menghidupi Pancasila. Tatanan kehidupan masyarakat Indonesia berdasarkan Pancasila menjadi tradisi historis yang menjaga keutuhan kehidupan masyarakat. Pancasila sebagai historical experience selalu dipahami dalam berbagai tantangan zaman. Proses pemahaman selalu dinamis dan reflektif dalam konteks pluralisme masyarakat karena tindakan memahami selalu ada dalam waktu dan historitasnya. Pancasila hendaknya dipahami dalam setiap tumpukan kenyataan konteks kebangsaan yang dihadapi.

Founding fathers telah mewariskan Pancasila sebagai sistem nilai yang melandasi kehidupan masyarakat Indonesia. Sikap menolak Pancasila dari beberapa kelompok keagamaan, merupakan respons terhadap teks Pancasila, berdasarkan latar belakang pemahaman keagamaan. Dalam pandangan penulis sikap penolakan sebagai bentuk prapaham, merupakan suatu kewajaran dan dialami oleh setiap orang dalam proses pemahaman. Menjadi masalah jika, prapaham tersebut diyakini sebagai suatu pemahaman terhadap Pancasila, tanpa 
bersikap terbuka membiarkan Pancasila berbicara dalam sistem nilai tradisi dan relevansinya terhadap kepentingan kehidupan bersama sebagai Indonesia. Sehingga yang harus dilakukan untuk mencegah adanya sikap radikal dalam menolak Pancasila yakni dialog. Dialog untuk mempercakapkan nilai-nilai bersama yang sudah final, mengikat, dan menjaga keutuhan masyarakat yakni Pancasila.

Pancasila tidak seperti ideologi-ideologi lainnya yang merupakan hasil pemikiran seorang saja, tetapi Pancasila merupakan rumusan dari para pendiri bangsa yang menyadari realita kehidupan masyarakat Indonesia (Soedarso, 2006). Kondisi pluralisme di Indonesia terkhususnya beragamnya agama-agama, tidak memungkinkan untuk memakai salah satu agama sebagai makna general yang digunakan oleh seluruh masyarakat. Oleh karenanya Islam tidak bisa menjadi agama negara dan dasar negara. Indonesia bukanlah 'negara agama, maupun negara sekuler'. Namun, negara yang menjunjung tinggi keberagamaan. Wacana tentang Pancasila tidak boleh mengalami stagnasi. Pancasila harus selalu dipahami dalam wacana baru dengan melihat tantangan kehidupan masyarakat Indonesia saat ini. Dasar agama-agama hidup secara bersama di negara Indonesia adalah Pancasila sebagai religiositas bangsa Indonesia. Agama-agama tidak bisa hidup bersama dan bersatu berdasarkan identitas primordial, maka jelas kehidupan bersama agama-agama dapat terjalin karena Pancasila.

Menurut Hans Kung, “tidak ada perdamaian antarbangsa tanpa perdamaian agama-agama, dan tidak ada perdamaian agama-agama tanpa dialog antar agama (Kung, 1998)". Konsep keberagamaan yang ada dalam Pancasila menciptakan kemanusiaan yang sederajat, sesuai dengan apa yang dimaksud oleh parlemen agama-agama dunia sebagai kebutuhan yang paling pokok karena setiap manusia harus diperlakukan secara manusiawi.

Perjumpaan agama-agama merupakan perjumpaan setiap masyarakat Indonesia yang hidup atas dasar Pancasila sebagai teks bersama. Dialog agama-agama yang dibangun dalam konteks Indonesia, hendak menyadari nilai-nilai Pancasila yang menyetarakan dan mempersatukan. Kehidupan bersama agama-agama merupakan relasi saling melengkapi dan saling mengisi. Dialog lintas agama 
merupakan sebuah kebajikan, karena orang yang berdialog disebut sebagai being religious dan tidak hanya having religion. Orang-orang yang being religious akan selalu menjunjung tinggi nilai-nilai ajaran agama, bukan hanya aturan-aturan agama, sehingga "mereka tidak hidup dari agama-agama ayat, akan tetapi dari agama-agama nilai (Timo, 2017)."

Agama bukan sekedar persoalan teoritis, tentang persoalan masa lalu, persoalan bagi ahli teks-teks kuno. Akan tetapi agama adalah lived life atau kehidupan yang dijalani, maka beragama selalu teraplikasikan dalam eksistensi semua umat religius setiap hari (Kung, Almirzanah, \& Philips, 2008). Konsep "Ketuhanan Yang Maha Esa", tidak bisa dipahami hanya sebatas "siapa yang mempercayai Tuhan" atau dalam konsepsi monoteisme. Dengan demikian terlalu menyederhanakan Sila pertama jika mengatakan bahwa hanya agama dengan paham monoteis yang sangat Pancasilais, karena percaya kepada Tuhan yang satu. Agama apapun datangnya dari yang SATU, dengan berbagai penyebutan mislanya; Yahweh, Allah, Sang Hyang Widi, Sangkan parning dumadi, yang maha abdi, dan sebagainya (Noor \& Ferry Muhammadsyah Siregar, 2014). Menurut Yudi Latif, Pancasila menghendaki nilai-nilai Ketuhanan yang positif, bersifat inklusif, membebaskan, memuliakan keadilan dan persaudaraan (Latif, 2012). Kung juga menekankan pentingnya setiap agama bersikap inklusif untuk menerima keberadaan agama lain dengan kepercayaan yang dimiliki (Kung et al., 2008). Konsep Sila Pertama, memperlakukan setiap individu sederajat dan manusiawi, di titik kemanusiaanlah agama dan Pancasila bertemu dan saling melengkapi (Prastowo, 2015).

Dialog tidak hanya suatu keharusan sosial, tetapi juga tindakan yang dilakukan atas dasar kesadaran religius. Kesadaran religius, kesadaran keagamaan, kesadaran manusia yang juga melibatkan yang Ilahi. Kesadaran manusiawi seperti ini berlaku sama bagi pemeluk agama apapun. Pada titik manusiawi inilah manusia dengan keragaman agamanya berjumpa satu dengan yang lain secara setara, dan rendah hati di depan yang Ilahi (Titaley, 2013). Masyarakat harus diterima dengan kebebasan untuk memeluk agama dan kepercayaan apapun. Nilai-nilai agama lain tidak harus disangkal, tetapi kritik 
harus dilakukan terhadap sesuatu yang dianggap tidak bernilai. Dialog dibangun dalam sikap kritis, dengan tanggung jawab untuk menjelaskan dengan baik, tanpa bersikap eksklusif (Kung, Almirzanah, \& Philips, 2008).

Pancasila sebagai teks dialog dalam kehidupan agama-agama hendaknya membangun sikap saling menghargai, saling melindungi, saling menghormati, agar tercipta kerukunan umat beragama. Kehidupan bersama agama-agama di Indonesia akan terjalin dengan baik jika Pancasila benar-benar dihidupi. Diwujudnyatakan dan dijaga sebagai suatu identitas yang tanpanya masyarakat Indonesia bukanlah Indonesia dalam arti yang sesungguhnya. Tanpanya agama-agama tidak bisa hidup berdampingan, menjadi suatu kesatuan dalam keberagaman. Indonesia tanpa kerukunan kehidupan beragama adalah kegagalan memahami Indonesia. Agama-agama hidup dalam keunikannya masing-masing yakni dogma dan doktrin keagamaan, tetapi agama-agama juga harus hidup dalam kesadaran berbangsa dan bernegara. Dengan demikian masyarakat memiliki loyalitas ganda yakni loyal kepada agama dan loyal kepada negara. Dialog yang dilakukan oleh agama-agama saat ini, tidak bisa lagi mempertentangkan dogma-dogma agama dengan tujuan klaim kebenaran. Dialog juga tidak hanya terbatas pada tindakan untuk menciptakan rekonsiliasi saat timbul konflik antaragama. Dialog dalam kehidupan sehari-hari dan dialog kerja menjadi penting untuk membicarakan tantangan sosial masyarakat. Sehingga dialog tidak terbatas pada tingkat intelektual dan spiritual, tetapi juga dialog aksi dengan menyadari persoalan-persoalan kemanusiaan yang terjadi dalam kehidupan masyarakat.

\section{SIMPULAN}

Di awal penulisan artikel ini, penulis memahami Pancasila sebagai teks bersama dialog lintas agama merupakan suatu strategi dalam menghadapi kondisi kehidupan beragama saat ini. Akan tetapi penulis sampai pada suatu titik memandang Pancasila sebagai teks dialog lintas agama melampaui konsepsi. Pancasila adalah suatu teks yang dimana masyarakat Indonesia hidup di dalam sejarah dan dipengaruhi oleh sejarah. Disadari atau tidak, dikehendaki ataupun 
tidak, terdapat nilai-nilai bersama sebagai masyarakat Indonesia yakni nilai Pancasila yang tertanam dan mempengaruhi kehidupan bersama. Dengan demikian melampaui suatu konsepsi, nilai-nilai Pancasila harus dipahami sebagai penuntun atau landasan dalam setiap bentuk strategi dialog lintas agama.

Dalam seluruh langkah dialog lintas agama, Pancasila tidak bisa dianggap hanyalah dasar negara yang tidak memiliki kaitan dan kehilangan relevansi. Bagian akhir tulisan ini ingin menekankan bahwa, agama-agama di Indonesia dalam menghadapi realitas keagamaan yang ada, "tidak mungkin tidak" tetap bertekad tinggal di rumah Indonesia dengan fondasi Pancasila karena adanya kehendak untuk bersatu. Memahami Pancasila dalam Hermeneutik dan teks historis Gadamer membuat Pancasila dapat dipahami secara dinamis, terbuka dan relevan dalam setiap perkembangan kehidupan masyarakat Indonesia. Sehingga memahami Pancasila bukanlah suatu indoktrinasi yang statis. Teori Hans Kung juga membantu dalam melihat Pancasila sebagai nilai bersama agama-agama. Pancasila memuat nilai substansi dari agama-agama, sehingga Pancasila tidak bertentangan dengan agama manapun di Indonesia. Dengan demikian dialog yang diterangi, dituntun dan dilandasi oleh nilai-nilai Pancasila mampu menciptakan kerukunan, kesetaraan, serta kedamaian. Sehingga pluralisme sangat dihargai dan dimaknai karena keunikan yang merupakan pemberian Tuhan bagi Indonesia.

\section{DAFTAR PUSTAKA}

Abdullah, T. (1998). Kata Pengantar. In S. Bahar \& N. Hudawati (Eds.), Risalah Sidang Badan Penyelidikan Usaha-Usaha Persiapan Kemerdekaan Indonesia (BPUPKI) - Panitia Persiapa Kemerdekaan Indonesia (PPKI) 28 Mei 1945-22 Agustus 1945. Sekertariat Negara RI.

Amelia, L., Purbolaksono, A., Muhammad Reza Hermanto, \& Syahayani, Z. (2016). In d o n e s i a 2016 (Vol. 2, Issue 1). Research, The Indonesian Institute center for republic policy.

Bagir, Z. A., Ahnaf, M. I., Tahun, M., \& Asyhari, B. (2013). Laporan Tahunan Kehidupan Beragama di Indonesia 2012 (S. Cholil (Ed.)). 
center for religious and crosscultural studies, Universitas Gadjah mada Yogyarakarta.

Bahar, S., \& Hudawati, N. (Eds.). (1998). Risalah Sidang Badan Penyelidikan Usaha-Usaha Persiapan Kemerdekaan Indonesia (BPUPKI) - Panitia Persiapa Kemerdekaan Indonesia (PPKI) 28 Mei 1945-22 Agustus 1945 (4th ed.). Sekertariat Negara RI.

Bolo, A. D., Samho, B., Djunatan, S., \& Laku, S. K. (2012). Pancasila Kekuatan Pembebas (Dwikoratno \& Lani (Eds.)). kanisius.

Creswell, J. W. (2010). Research Design Pendekatan Kualitatif, Kuantitatif dan Mixed (3rd ed.). Pustaka Belajar.

Dahm, B. (1987). Soekarno dan Perjuangan Kemerdekaan. LP3ES.

Darmaputera, E. (1992). Pancasila: Identitas dan Modernitas; Tinjauan Etis dan Budaya. BPK Gunung Mulia.

Dubut, D. (2009). Dialog: Gaya Hidup Dalam Masyarakat Majemuk. In Dialog Antarumat Beragama: Membuka Babak Baru dalam Hubungan Antarumat Beragama. BPK Gunung Mulia.

Gadamer, H.-G. (2004). Kebenaran dan Metode: Pengantar Filsafat Hermeneutika. Pustaka Belajar.

Hadirman, F. B. (2015). Memahami sebagai Kesepahaman: Gadamer dan Hermeneutik Filosofis. In Widiantoro (Ed.), Seni Memahami; Hermeneutik dari Schleiermacher sampai Derrida. kanisius.

Hardiman, F. B. (2014). Makalah untuk kuliah terakhir Kelas Filsafat Seni Memahami: Hermeneutika Dari Schleiermacher Sampai Gadamer.

Hendropuspito. (1983). Sosiologi Agama. kanisius.

Huntington, S. P. (1996). The Clash of Civilizations and the Remaking of World Order. SIMON and SCHUSTER.

Ihsanuddin. (2018, May). Jalan Panjang Pemerintah Bubarkan HTI. Kompas.Com.

https://nasional.kompas.com/read/2018/05/08/10463051/jalanpanjang-pemerintah-bubarkan-hti

Kaelan, H. (2013). Negara Kebangsaan Pancasila: Kultural, Historis, 
Filosofis, Yuridis, dan Aktualisasinya. PARADIGMA.

Kartodirdjo, S., Posponegoro, M. D., \& Notosusanto, N. (1957). Sejarah Nasional Indonesia (F. A. Sutjipto (Ed.)). Departemen Pendidikan dan Kebudayaan.

Kasenda, P. (2014). Sukarno, Marxisme dan Leninisme: Akar Pemikiran Kiri dan Revolusi Indonesia. Komunitas Bambu.

Kholiludin, T. (2014). Pancasila dan Transformasi Religiositas Sipil di Indonesia. Universitas Kristen Satya Wacana.

Kung, H. (1998). A Global Ethic for Global Politics and Economics. Oxford University Press.

Kung, H. (2003). Kata Pengantar. In N. A. Likumahuwa (Ed.), Satu Bumi Banyak Agama; Dialog Multi-Agama dan Tanggung Jawab Global (1st ed., pp. 1-282). Gunung Mulia.

Kung, H., Almirzanah, S., \& Philips, G. (2008). Jalan Dialog Hans Küng dan Perspektif Muslim (N. Martiam (Ed.)). CRCS Universitas Gadjah Mada dan Mizan.

Kung, H., \& Kuschel, K.-J. (1999). Etika Global. Pustaka Belajar.

Kuswanjono, A. (2006). Pluralisme Pancasila. Jurnal Filsafat, 39(1), 7793.

Latif, Y. (2012). Negara Paripurna: Historitas, Rasionalitas, dan Aktualitas Pancasila. PT Gramedia Pustaka Utama.

Latif, Y. (2015). Revolusi Pancasila. Mizan.

Maarif, A. S., Sinaga, M. L., Mulia, S. M., Hiariej, E., Asfinawati, Sudjatmiko, B., Khisbiyah, Y., \& Pariela, T. D. (2012). Politik Identitas Dan Masa Depan Pluralisme Kita (I. Ali-Fauzi \& S. R. Panggabean (Eds.)). yayasan abas demokrasi.

Malaka, T. (2000). Aksi Massa; Tan Malaka (1926). Teplok Press.

Metafisika, D. P., \& Gadamer, H. (n.d.). Tingkatan Bahasa Jawa Dalam Perspektif Metafisika Hans-Georg Gadamer Oleh: Tri Tarwiyani 1.

Noor, N. M., \& Ferry Muhammadsyah Siregar (Eds.). (2014). Etika Sosial dalam Interaksi Lintas Agama. 
Palmer, R. E. (2005). Hemeneutik; Teori Baru Mengenai Interpretasi. Pustaka Pelajar.

Prastowo, B. C. T. (2015). Prof. N. Drijarkara: me-NEGARA, mengINDONESIA, PANCASILA dari sudut pandang filsafat manusia. (A. Haryono (Ed.)). Pusat Kajian Filsafat dan Pancasila Universitas Drijarkara.

Priana, I. M. (2017). Misi Gereja Kristen Protestan di Bali Periode 20122016, Dalam Prespektif Pancasila. Fakultas Teologi Universitas Kristen Satya Wacana.

Rahmat, S. T. (2017). Dialog Antropologis Antaragama Dengan Spiritualitas Passing Over. Ilmiah Agama Dan Sosial Budaya, 2(2), 181-198. https://doi.org/10.15575/jw.v2i2.1704

Soedarso. (2006). Pengembangan Sistem Filsafat Pancasila. Jurnal Filsafat, 39(1), 42-56.

Soekarno, I. (1964). Di bawah Bendera Revolusi (3rd ed.). Di bawah Bendera Revolusi.

Soeprapto, S. (2013). Konsep Muhammad Hatta Tentang Implementasi Pancasila Dalam Perspektif Etika Pancasila. Jurnal Filsafat, 23(2), 99-116. https://doi.org/10.22146/jf.13194

Sukiratnasari, A. (2015). Etika Sosial Dalam Ruang Publik. In N. M. Noor (Ed.), Manual Etika Lintas Agama Untuk Indonesia. Globalethics.net.

Sumartana. (1999). Kata Pengantar. In Etika Global. Pustaka Pelajar.

Suseno, F. M. (2012). Prolog; Tambang Emas Bagi Yang Ingin Mengerti Indonesia. In I. S. Ibrahim (Ed.), Negara Paripurna: Historitas, Rasionalitas, Dan Aktualitas Pancasila. PT Gramedia Pustaka Utama.

Timo, E. N. (2017). Meng-hari-ini-kan Injil di Bumi Pancasila: Bergereja Dengan Cita Rasa Indonesia. BPK Gunung Mulia.

Titaley, J. A. (2013). Religiositas Alinea Tiga. Satya Wacana University Press.

Widiyono, A. N. (2006). Dialog antar Agama dengan Immersion: Dari 
180 Jurnal Filsafat, Vol. 30, No. 2 Agustus 2020

Perjumpaan Menuju Kerja Bersama. Orientasi Baru, 15(1-2), 15-26. 